\title{
A comparison of the illness beliefs of people with angina and their peers: a questionnaire study Gill Furze*1, Alun Roebuck ${ }^{1}$, Peter Bull ${ }^{2}$, Robert JP Lewin ${ }^{1}$ and David R Thompson ${ }^{1}$
}

Address: ${ }^{1}$ British Heart Foundation Rehabilitation Research Unit, Department of Health Sciences, University of York, Heslington, York, UK and ${ }^{2}$ Department of Psychology, University of York, Heslington, York, UK

E-mail: Gill Furze* - gf107@york.ac.uk; Alun Roebuck - ar25@york.ac.uk; Peter Bull - peb1@york.ac.uk; Robert JP Lewin - RJPL1@york.ac.uk; David R Thompson - drt2@york.ac.uk

${ }^{*}$ Corresponding author

Published: 20 February 2002

BMC Cardiovascular Disorders 2002, 2:4
Received: 30 November 200 I

Accepted: 20 February 2002

This article is available from: http://www.biomedcentral.com/|47|-226I/2/4

(C) 2002 Furze et al; licensee BioMed Central Ltd. Verbatim copying and redistribution of this article are permitted in any medium for any purpose, provided this notice is preserved along with the article's original URL.

\begin{abstract}
Background: What people believe about their illness may affect how they cope with it. It has been suggested that such beliefs stem from those commonly held within society. This study compared the beliefs held by people with angina, regarding causation and coping in angina, with the beliefs of their friends who do not suffer from angina.

Methods: Postal survey using the York Angina Beliefs Questionnaire (version I), which elicits stress attributions and misconceived beliefs about causation and coping. This was administered to 164 people with angina and their non-cohabiting friends matched for age and sex. 132 people with angina and 94 friends completed the questionnaire.

Results: Peers are more likely than people with angina to believe that angina is caused by a worn out heart $(p<0.01)$, angina is a small heart attack $(p=0.02)$, and that it causes permanent damage to the heart $(p<0.00 I)$. Peers were also more likely to believe that people with angina should take life easy $(p<0.01)$ and avoid exercise $(p=0.04)$ and excitement $(p<0.01)$.

Conclusions: The beliefs of the peer group about causation and coping in angina run counter to professional advice. Over time this may contribute to a reduction in patient concordance with risk factor reduction, and may help to create cardiac invalids.
\end{abstract}

\section{Background}

When people attribute causes for their illness or develop coping strategies, they are influenced by cultural, institutional, social and personal factors. These affect how people form mental representations of their illness, and develop methods for dealing with it [1]. Leventhal's self regulatory model of illness behaviour describes parallel processing of internal and external stimuli to generate: a subjective perception of the illness, the emotions associat- ed with this process (fear or distress), coping responses, and appraisals of outcome [2]. In the self regulative model it is argued that people are problem solvers who will try to achieve an ideal state, and that behaviour in illness depends on how the person builds cognitive representations of their current state and the methods that they have for appraising progress [3]. A misconceived or maladaptive belief about an illness could help to create a misconceived or maladaptive coping strategy, which could affect emo- 
tional response (for example fear) and eventually cause a faulty appraisal which further feeds back to compound future representations of this (and perhaps other) illnesses. According to this model, illness representations are mediated by influences that are not explained by the bio-medical model of illness. These can include influences from the social environment [4], which can affect the strategies developed to cope with the illness. However the self-regulatory system is not static, particularly in chronic disease, as illness severity generally changes over time. Representational, coping and appraisal processes may be updated as new information is received from the media, health practitioners and from peers [2].

Biomedical concepts are prone to be misconceived, as they are difficult for the layperson to understand [5]. Misconceptions may develop through a reciprocating network of faulty ideas [6]. There is often an oversimplification of complex biomedical concepts [7], which may be reinforced and legitimised by external influences [6].

Coronary heart disease accounts for just under a quarter of all deaths in the United Kingdom (UK) [8]. Angina, a manifestation of coronary heart disease, affects over 1.4 million people in the UK [9], with an estimated 22,600 new angina cases diagnosed each year [10]. It is estimated that up to $20 \%$ of all men in the age group 65-74 suffer from angina [11] and it is possible that most people from late middle age onwards will know somebody who suffers from angina.

The effect of misconceptions on recovery post heart attack has been reported in two seminal studies. Wynn [12] stated that misconceptions about heart attack were a cause of undue fear and anxiety suffered by over half of the $400 \mathrm{pa}-$ tients that he interviewed, and that this led to unwarranted disability and an adoption of an unduly careful lifestyle. For example interviewees often believed that every chest pain was a further heart attack, and that permanent damage was being caused to the heart by angina, consequently they also believed that work would cause more damage [12].

Maeland and Havik devised the 10 item Cardiac Misconceptions Scale [13] for a study of 383 patients post heart attack. They reported that those people with a greater number of misconceptions about their heart attack had reduced expectations of autonomy post MI [14] and were more likely to be subsequently hospitalized for chest pain that was not diagnosed as a further MI (false alarms) [15]. Those people with fewer misconceptions had higher levels of perceived global health [16] and were more likely to return to work [17]. It was also noted that although education aimed at counteracting the misconceptions was successful in the short term, over time some of the misconceptions returned [18]. It may be that either societal influences or the durability of some misconceptions caused the patients to regain those that had been previously dispelled.

All of this suggests that societal beliefs about illness, including those held by peers of the sufferer, may reinforce misconceptions about illness and lead to the sufferer adopting inappropriate coping strategies.

People with angina and their close family often have access to the same information and may therefore be more likely to hold beliefs that are consistent with those of health professionals. Friends and acquaintances are less likely to receive such information and might be a constant source of reinforcement of inappropriate beliefs and behaviours, which may have the effect of counteracting appropriate advice.

The Cardiac Misconceptions Scale is specific to MI, and would not necessarily be of use in an angina population. As part of an ongoing study of the effect of angina beliefs on illness experience, an angina beliefs questionnaire was developed - the York Angina Beliefs Questionnaire; version 1 . The beliefs forming the questionnaire are statements about angina that are either misconceived or potentially maladaptive. They were derived from patient interviews about the experience of angina [19], supplemented by two statements about angina taken from the Wynn study . A longitudinal study which includes the York Angina Beliefs Questionnaire (YABQ) is underway, in order to discover whether such beliefs predict illness experience and quality of life in a cohort of people with angina, as this work has not been undertaken previously. Early results show significant correlations between scores on the YABQ and anxiety, depression and physical limitation [20]. The results of the longitudinal study will be published in a separate report in the future.

For this study, the pilot version of the questionnaire was administered to a sample of people who suffered from angina and the opportunity was taken to discover the beliefs of the non-cohabiting friends of the respondents.

\section{Methods \\ Design}

Postal questionnaire survey.

\section{Measures}

The York Angina Beliefs Questionnaire version 1 (Fig 1) is designed to elicit beliefs about causation and coping in angina that are misconceived or potentially maladaptive. It consists of 16 statements about angina with answers scored on a five-point Likert scale ranging from 0 (strong- 
THE YORK ANGINA BELIEFS QUESTIONNAIRE (version 1) We want to know your views and beliefs about why people get angina and what they should do about it.

It is important that you answer every question. Don't spend too long thinking about your answers - the first thing you thought of is what we want to know.

For each question please tick one circle. Please don't leave any out.

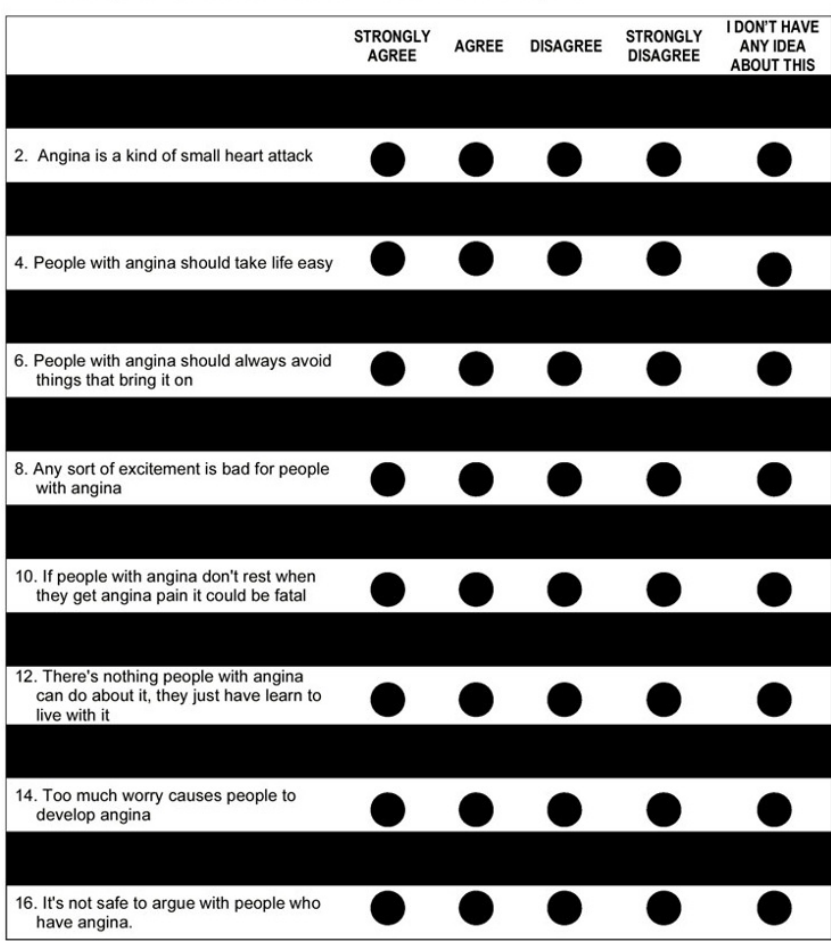

Figure I

The York Angina Beliefs Questionnaire (version I)

ly disagree) to 4 (strongly agree), with "I don't have any idea about this" scoring 2 . The score range for the total questionnaire is from 0 to 64 . One month test - retest for scale stability among the sample was satisfactory (Pearson's $\mathrm{r}=.87, \mathrm{p}=0.0005)$, and alpha score of internal reliability was acceptable at .803 .

\section{Sample}

162 people who were post myocardial infarction and who suffered from angina were recruited via the press and from coronary support groups. Each person with angina was asked to recruit a friend who did not suffer from angina, who was of similar age and the same sex. Family members and people living with the person with angina were excluded.

The survey achieved a response rate of $81 \%$, (132 completed questionnaires) from people with angina and 58\% (94 completed questionnaires) from peers.

The age and sex of respondents are reported in Table 1. There was no significant difference in age (mean $=62$ years, standard deviation $[\mathrm{sd}] \mathrm{8.89}, \mathrm{t}=1.04, \mathrm{p}=0.30$ ) or gender $\left(\chi^{2}=1.35, \mathrm{p}=0.25\right)$ between the two groups. (Nine respondents [ 6 people with angina and 3 peers] did not provide details of age or sex but did complete the questionnaire, and their data are included in the analysis of the questionnaires).

\section{Analyses}

Interval data was analysed with t-test $(\mathrm{t})$, nominal data with chi-square $\left(\chi^{2}\right)$ and ordinal data with Mann Whitney U test ( $\mathrm{z}=$ standardized statistical value of the Mann Whitney test) using SPSS version 10 for Windows [21].

\section{Results}

There was a small difference between patient and peer groups in the total score on the questionnaire (mean score peers, 31.60, [sd 8.60]; mean score people with angina 29.42, [sd 9.21]; $\mathrm{t}=-1.80,95 \%$ confidence interval of the mean [CI] -4.56 to $0.21, \mathrm{p}=0.07$ ). (Higher scores on the total score (out of a possible 64) denote a greater number of misconceptions). The responses to the individual items are presented in Table 2. It can be seen that a number of responses differ, with more of the peer group agreeing with items 2, 4, 7, 8, 9 and 15 .

\section{Discussion}

From the results it can be seen that peers are more likely than people with angina to believe that angina is caused by a worn out heart, that it causes permanent damage to the heart and that angina was a small MI. These are misconceptions $[11,12]$. It seems possible that people holding these threatening beliefs would be less likely to invite an angina sufferer to take part in exciting or active leisure pursuits, and could lend weight to Feltovich et al.'s [6] suggestion that misconceptions held by peers may reinforce the network of misconceptions held by the angina sufferer. Maeland and Havik [17] reported that holding greater numbers of misconceptions affected recovery and quality of life post MI. It is possible that people with angina will manifest the same response to high misconception levels, further research into the interaction between misconceptions and morbidity is necessary.

Peers were also significantly more likely to believe that people with angina should take life easy, not exercise and avoid excitement, again these are misconceptions. Friends who believe that people with angina should avoid exercise and take life easy may seek to prevent exertion and "overexcitement" in the person with angina. Petrie \& Weinman [22] state that cardiac invalidism (adoption of a passive, helpless role, accompanied by a belief that any form of overexertion will precipitate $\mathrm{MI}$ ) is often reinforced by family and friends being overprotective. This can lead to a destructive cycle with a reduction in fitness [22]. Lewin has theorised that because fitness determines the threshold at which the heart muscle becomes ischaemic, loss of 
Table I: Breakdown of respondents by age and sex

\begin{tabular}{|c|c|c|c|}
\hline & Total sample $\left(\mathrm{N}=217^{*}\right)$ & Peers $\left(n=91^{*}\right)$ & People with angina $\left(n=126^{*}\right)$ \\
\hline Mean age (yrs) & 62.35 & 61.62 & 62.88 \\
\hline Range (yrs) & $32-83$ & $38-80$ & $32-83$ \\
\hline Standard deviation & 8.89 & 8.96 & 8.84 \\
\hline Male n (\%) & $150(69.1)$ & $59(64.8)$ & 91 (72.2) \\
\hline Female n (\%) & $67(30.9)$ & $32(35.2)$ & $35(27.8)$ \\
\hline
\end{tabular}

* demographic data missing on 9 respondents

Table 2: Questionnaire results: comparisons of peers and people with angina

\begin{tabular}{|c|c|c|c|c|}
\hline Statement & $\begin{array}{l}\text { Person with angina } \\
\text { mean score }(\mathrm{sd})\end{array}$ & $\begin{array}{l}\text { Peer mean score } \\
(\text { (sd) }\end{array}$ & $\begin{array}{l}\text { Mann Whitney } \\
\mathrm{z} \text { value }\end{array}$ & Sig. Level (two tailed) \\
\hline $\begin{array}{l}\text { I. People with angina should stop what they are doing } \\
\text { when they get an angina attack }\end{array}$ & $3.22(0.83)$ & $3.27(0.72)$ & -0.02 & 0.98 \\
\hline 2. Angina is a kind of small heart attack & $1.57(1.17)$ & $1.95(1.17)$ & -2.41 & 0.02 \\
\hline $\begin{array}{l}\text { 3. People develop angina because they have too much } \\
\text { stress in their lives }\end{array}$ & $1.90(1.20)$ & $1.74(1.02)$ & -0.88 & 0.38 \\
\hline 4. People with angina should take life easy & $1.75(1.15)$ & $2.18(1.15)$ & -2.74 & $<0.01$ \\
\hline $\begin{array}{l}\text { 5. People who work too hard are likely to develop } \\
\text { angina }\end{array}$ & $1.23(1.04)$ & $1.17(0.92)$ & -0.05 & 0.96 \\
\hline $\begin{array}{l}\text { 6. People with angina should always avoid things that } \\
\text { bring it on }\end{array}$ & $2.78(1.13)$ & $3.02(0.79)$ & -0.86 & 0.39 \\
\hline 7. It's not advisable for people with angina to exercise & $0.96(0.94)$ & $1.13(0.87)$ & -2.04 & 0.04 \\
\hline 8. Any sort of excitement is bad for people with angina & $1.17(0.97)$ & $1.46(0.92)$ & -2.75 & $<0.01$ \\
\hline 9. Angina is caused by a worn out heart & $1.07(0.95)$ & $1.37(0.92)$ & -3.01 & $<0.01$ \\
\hline $\begin{array}{l}\text { 10. If people don't rest when they get angina it could } \\
\text { be fatal }\end{array}$ & $2.28(1.16)$ & $2.56(1.01)$ & -1.65 & 0.10 \\
\hline II. People with angina must stay calm & $2.86(0.86)$ & $2.79(0.89)$ & -0.68 & 0.50 \\
\hline $\begin{array}{l}\text { 12. There's nothing people with angina can do about it, } \\
\text { they just have to learn to live with it. }\end{array}$ & $1.64(1.25)$ & $1.79(1.24)$ & -0.90 & 0.37 \\
\hline 13. Rest is the best treatment for angina & $2.18(1.16)$ & $2.13(1.15)$ & -0.36 & 0.72 \\
\hline 14. Too much worry causes people to develop angina & $1.80(1.19)$ & $1.64(1.01)$ & -0.82 & 0.41 \\
\hline 15. Angina pain causes permanent damage to the heart & $1.42(1.03)$ & $1.81(0.90)$ & -3.58 & $<0.001$ \\
\hline 16. It's not safe to argue with people who have angina & $1.61(1.12)$ & $1.60(1.01)$ & -0.15 & 0.88 \\
\hline
\end{tabular}

$z=$ standardised statistical value of the Mann Whitney test

fitness leads to angina being produced at a lower level of exertion, thus reinforcing the patient's belief that exercise is dangerous, in a positive feedback loop of increasing invalidism [23].

\section{Conclusions}

The English National Service Framework for Heart Disease [9] states that cardiac rehabilitation should promote return to a full and normal life. The peers of the people with angina in this study held beliefs that run counter to this message. If people with angina live in a community that reinforces maladaptive coping beliefs, then concordance with professional advice (which is often not reinforced regularly) may be replaced over time with compliance with societal beliefs. This has implications for continuing risk factor reduction, and the possible creation of cardiac invalids. Further research is required on the interaction of illness beliefs between peers and people with angina, to discover whether there is an effect on illness behaviour caused by peer reinforcement of coping misconceptions

\section{Competing interests}

None declared. 


\section{References}

I. Leventhal H, Benyamini Y, Brownlee S, Diefenbach M, Leventhal EA, Patrick-Miller L, Robitaille C: Illness representations: theoretical foundations. In: Perceptions of Health and IIIness 1997, 19-45

2. Leventhal $H$, Diefenbach $M$, Leventhal EA: Illness cognition: using common sense to understand treatment adherence and affect cognition interactions. Cognitive Therapy and Research 1992, 16:143-163

3. Leventhal H, Cameron L: Behavioral theories and the problem of compliance. Patient Education and Counseling. 1987, I 0: I I7-138

4. Cioffi D: Beyond attentional strategies: a cognitive-perceptual model of somatic interpretation. Psychological Bulletin 1991, | 09:25-4 |

5. Ley P: Psychological studies of doctor-patient communication. In: Contributions to Medical Psychology 1977, I:9-42

6. Feltovich P, Spiro RJ, Coulson RL: The nature of conceptual understanding in Biomedicine: the deep structure of complex ideas and the development of misconceptions. In: Cognitive Science in Medicine: Biomedical Modeling. 1989, I I3-I72

7. Coulson RL, Feltovich PJ, Spiro RJ: Foundations of a misunderstanding of the ultrastructural basis of myocardial failure: a reciprocation network of oversimplifications. Journal of Medicine and Philosophy 1989, I4:109-146

8. NHS Centre for Reviews and Dissemination: Cholesterol and coronary heart disease: screening and treatment. Effective Health Care 1998, 4:1-16

9. Department of Health: National Service Framework for Coronary Heart Disease. London: Department of Health; 2000

10. Ghandi MM, Lampe FC, Wood DA: Incidence, clinical characteristics and short-term prognosis of angina pectoris. British Heart Journal 1995, 73:193-198

II. Task Force of the European Society of Cardiology: Management of stable angina pectoris. European Heart Journal 1997, I 8:394-4I 3

12. Wynn A: Unwarranted emotional distress in men with ischaemic heart disease. Medical Journal of Australia 1967, 2:847-85 I

13. Maeland JG, Havik OE: Measuring cardiac health knowledge. Scandinavian Journal of Caring Sciences 1987, 7:23-31

14. Havik OE, Maeland JG: Knowledge and expectations: perceived illness in myocardial infarction patients. Scandinavian Journal of Psychology 1987, 28:281-292

15. Maeland JG, Havik OE: Use of health services after a myocardial infarction. Scandinavian Journal of Social Medicine 1989, 17:93-102

16. Maeland JG, Havik OE: Self-assessment of health before and after a myocardial infarction. Social Science and Medicine 1988, 27:597-605

I7. Maeland J, Havik O: Psychological predictors for return to work after a myocardial infarction. Journal of Psychosomatic Research | $987,31: 47|-48|$

18. Maeland JG, Havik OE: The effects of an in-hospital educational programme for myocardial infarction patients. Scandanavian Journal of Rehabilitation Medicine 1987, 19:57-65

19. Furze G, Lewin RJP, Roebuck A, Bull P, Thompson DR: Attributions and misconceptions in angina: an exploratory study. Journal of Health Psychology 2001, 6:501-510

20. Furze G, Roebuck A, Lewin B, Bull P, Thompson DR: Development of the York Angina Beliefs Questionnaire. Poster presentation at the European Health Psychology Conference St Andrews, Scotland, 200 I

21. SPSS Inc: Statistical Package for the Social Sciences version 10.0: SPSS Inc; 1999

22. Petrie KJ, Weinman JA: Illness representations and recovery from myocardial infarction. In: Perceptions of Health and IIIness |997, 44|-465

23. Lewin B: The psychological and behavioural management of angina. Journal of Psychosomatic Research 1997, 43:453-462
Publish with BioMed Central and every scientist can read your work free of charge

"BioMedcentral will be the most significant development for disseminating the results of biomedical research in our lifetime." Paul Nurse, Director-General, Imperial Cancer Research Fund

Publish with BMC and your research papers will be:

- available free of charge to the entire biomedical community

- peer reviewed and published immediately upon acceptance

- cited in PubMed and archived on PubMed Central

- yours - you keep the copyright

Submit your manuscript here:

http://www.biomedcentral.com/manuscript/
BioMedcentral.com editorial@biomedcentral.com 